\title{
PENGARUH PERBEDAAN DOSIS NaOH PADA PEMBUATAN SABUN DENGAN METODE ANOVA SATU ARAH DAN PENENTUAN PERBANDINGAN 3 JENIS MINYAK SEBAGAI BAHAN UTAMA DENGAN METODE AHP PADA PRODUK SABUN MANDI RAMAH LINGKUNGAN
}

\author{
Selamet Riadi'), Dede Rukmayadi' ${ }^{2}$, Iwan Roswandi ${ }^{3)}$, Roy Wangitan ${ }^{4}$ ) \\ ${ }^{1,3)}$ Program Studi Teknik Industri Universitas Mercu Buana Jakarta, \\ ${ }^{2)}$ Program Studi Teknik Industri dan ${ }^{4)}$ Program Studi Teknik Kimia Institut Sains dan Teknologi Al Kamal \\ e-mail: sriadi@yahoo.com; rukmayadi2010@gmail.com
}

\begin{abstract}
ABSTRAK
Sejalan dengan meningkatnya pertumbuhan jumlah penduduk, maka kebutuhan akan sabun juga meningkat. Ada beberapa pertimbangan yang memepengaruhi penggunaan sabun mandi kecocokan terhadap kulit, aroma, warna, ukuran, serta bentuk kemasan dan harga. Penelitian ini bertujuan untuk menganalisa pengaruh perbedaan konsentrasi NaOH pada pembuatan sabun mandi ramah lingkungan dengan metode anova dan menganalisa kebutuhan sabun mandi ramah lingkungan dengan perbandingan dari 3 jenis minyak dengan metode Analytical Hierarchy Process (AHP). Hasil dari penelitian ini dengan penambahan konsentrasi $\mathrm{NaOH}$ dengan konsentrasi dosis 5\%, 7,5\%, $10 \%$ dan 12,5\% mempengaruhi kenaikan pH dari sabun mandi yang dibuat artinya terjadi perbedaan pada pH sabun mandi tersebut dengan perbedaan konsentrasi NaOH. Dengan perhitungan validitas reliabilitas dan uji tukey, konsentrasi $\mathrm{NaOH}$ yang paling tepat digunakan untuk sabun mandi adalah 5\%. Pengambilan keputusan dengan metode perhitungan AHP maka diperoleh hasil sabun mandi yang paling disukai oleh masyarakat adalah sabun mandi dengan konsentrasi 5\%. Dengan nilai bobot akhir yang paling tinggi yaitu 0,585.
\end{abstract}

Kata kunci: Sabun, ANOVA, AHP

\section{ABSTRACT}

In line with increasing population growth, the need for soap has also increased. There are several considerations that affect the use of bath soap compatibility with skin, aroma, color, size, and shape of packaging and price. This study aims to analyze the effect of different concentrations of $\mathrm{NaOH}$ on the manufacture of environmentally friendly bath soap with the ANOVA method and analyze the need for environmentally friendly bath soap with a comparison of 3 types of oil with the Analytical Hirarchy Process (AHP) method. The results of this study with the addition of $\mathrm{NaOH}$ concentration with a dose concentration of 5\%, 7.5\%, $10 \%$ and $12.5 \%$ affect the increase in $\mathrm{pH}$ of the bath soap that is made meaning that there is a difference in the $\mathrm{pH}$ of the bath soap with a difference in the concentration of $\mathrm{NaOH}$. With the calculation of the validity of the reliability and the Tukey test, the most appropriate NaOH concentration used for soap is 5\%. Decision making using AHP calculation method shows that the most preferred soap by the public is shower soap with a concentration of $5 \%$. With the highest final weight value, 0.585 .

Keywords: Soap, ANOVA, AHP

\section{PENDAHULUAN}

Belakangan ini, masyarakat juga semakin sadar akan kebersihan menjaga tubuh dan kesehatan kulit. Selain dari segi harga dan kualitas, masyarakat juga semakin sadar bahwa penggunaan bahan kimia yang terlalu lama juga tidak baik untuk kesehatan, dan tidak semua jenis kulit mampu meneriman semua bahan kimia yang ada di dalam sabun mandi. Ada kulit yang bahkan sangat sensitif dengan kandungan kimia yang ada dalam sabun mandi.

Untuk di era sekarang ini kebanyakan orang lebih memilih untuk menggunakan bahan yang alami untuk perawatan diri. Selain dinilai lebih aman, hal ini juga berkaitan dengan kondisi lingkungan yang semakin lama semakin mengkhawatirkan. untuk mengatasi masalah kulit sensitif dan untuk membersihkan kulit dari kotoran dapat menggunakan bahan-bahan yang alami dan tidak berbahaya bagi kulit. Yaitu sabun ramah lingkungan dengan bahan utama dari minyak kelapa, minyak kelapa sawit dan minyak zaitun. 
Pengaruh Perbedaan Dosis NaOH pada Pembuatan Sabun dengan Metode ANOVA Satu Arah dan Penentuan Perbandingan 3 Jenis Minyak Sebagai Bahan Utama dengan Metode AHP pada Produk Sabun Mandi Ramah Lingkungan

Selamet Riadi, Dede Rukmayadi, Iwan Roswandi, Roy Wangitan

Permasalahan dari penelitian ini, apakah perbedaan konsentrasi $\mathrm{NaOH}$ memengaruhi hasil dari pembuatan sabun ramah lingkungan?, dan berapakah konsentrasi sabun yang cocok dan disukai oleh masyarakat yang mempunyai kulit sensitif dengan metode pendekatan AHP?

Sedangkan tujuan yang akan dicapai dalam peneltian ini untuk menganalisa pengaruh perbedaan konsentrasi $\mathrm{NaOH}$ pada pembuatan sabun mandi ramah lingkungan dengan metode anova dan menganalisa kebutuhan sabun mandi ramah lingkungan dengan perbandingan dari 3 jenis minyak dengan metode Analytical Hierarchy Process (AHP).

\section{TINJAUAN PUSTAKA}

\section{Penelitian Experimen}

Menurut Hadi [1] penelitian eksperimen adalah penelitian yang dilakukan untuk mengetahui akibat yang ditimbulkan dari suatu perlakuan yang diberikan secara sengaja oleh peneliti. Sejalan dengan hal tersebut, Penelitian eksperimen pada umumnya lebih menekankan pada pemenuhan validitas internal, yaitu dengan cara mengontrol/ mengendalikan/mengeliminir pengaruh faktor-faktor di luar yang dieksperimenkan yang dapat mempengaruhi hasil eksperimen [2].

\section{Karakteristik Penelitian Eksperimen}

Menurut Ary et al [3], ada tiga karakteristik penting dalam penelitian eksperimen, yaitu variabel bebas yang dimanipulasi, variabel lain yang berpengaruh dan dikontrol agar tetap konstan dan Observasi langsung oleh peneliti.

\section{Sabun}

Sabun mandi padat sangat akrab dalam kehidupan sehari-hari. Syarat mutu sabun mandi yang ditetapkan Standard Nasional Indonesia (SNI) untuk sabun yang beredar di pasaran hanya mencakup sifat kimiawi dari sabun mandi, yaitu jumlah asam lemak minimum $71 \%$, asam lemak bebas maksimum $2,5 \%$, alkali bebas dihitung sebagai $\mathrm{NaOH}$ maksimum $0,1 \%$, bagian zat yang tak terlarut dalam alkohol maksimum 2,5\%, kadar air maksimum $15 \%$, dan minyak mineral (negatif). Sementara sifat fisik sabun seperti daya membersihkan, kestabilan busa, kekerasan, dan warna belum memiliki standar [4].

Dalam bahan baku pembuatan sabun terdapat dua jenis, yaitu bahan baku dan bahan pendukung. Bahan baku dalam pembuatan sabun adalah minyak atau lemak dan senyawa alkali (basa). Bahan pendukung dalam pembuatan sabun digunakan untuk menambah kualitas produk sabun, baik dari nilai guna maupun dari daya tarik. Bahan pendukung yang umum dipakai dalam proses pembuatan sabun diantaranya natrium klorida, natrium karbonat, natrium fosfat, parfum, dan pewarna [5].

\section{Jenis-Jenis Sabun Mandi}

Sabun mandi biasanya dibuat dari campuran lemak (stearine) dan minyak kelapa (coconut natural oil atau CNO) dengan perbandingan 80/20 atau 90/10, dan sabun yang mempunyai lemak yang berlebih mempunyai perbandingan 50/50 atau 60/40 dan ada yang 7 sampai 10\% ditambahkan asam lemak bebas juga. Sabun kesehatan mengandung bahan seperti Triclosan dan Tri Chloro Carban (TCC) yang merupakan dua senyawa yang banyak digunakan sebagai antimicrobial.

Pada umumnya sabun yang akan diperdagangkan mengandung 10 sampai $30 \%$ air, dan jika sabun kekurangan air maka akan sulit larut. Hampir semua sabun memiliki parfum. Hal ini untuk menghilangkan aroma sabun yang asli. Sabun mandi dibuat dengan bahan pilihan yang mengandung $10-15 \%$ pelembab. 
Menurut [6] Jenis sabun batangan lainnya adalah sabun mandi kecantikan. Sabun mandi kecantikan adalah suatu produk sabun untuk perawatan kecantikan kulit wajah dan tubuh dengan formulasi yang sesuai untuk kulit. Memberikan zat-zat gizi dan nutrisi yang sangat diperlukan kulit dan membantu memelihara kulit dengan mempertahankan kelembaban kulit serta membantu pertumbuhan sel-sel baru jika terjadi kerusakan sel kulit. Pada sabun kecantikan busa harus lembut dan sifat basanya lebih rendah.

\section{Pemilihan Minyak}

Ada banyak minyak yang dapat digunakan untuk membuat sabun, diantaranya ada minyak kelapa, minyak kelapa sawit dan minyak zaitun. Minyak kelapa adalah minyak yang berwarna kuning pucat sampai tidak berwarna, atau lemak semi padat berwarna putih yang diperoleh dari daging buah kelapa digunakan secara luas dalam industri makanan dan produk kosmetika serta sabun. Minyak kelapa mengandung asam lemak rantai pendek sampai medium sekitar 57\% merupakan asam kaprat (C8) dan asam laurat (C12). Minyak kelapa mengandung 50\% asam laurat. Asam Laurat ini memiliki fungsi lain, yakni diubah menjadi monolaurin di dalam tubuh manusia. Monolaurin adalah monogliserida antiviral, antibakterial, dan antiprotozoal yang digunakan oleh sistem kekebalan tubuh manusia dan hewan untuk menghancurkan virus, bakteri, serta protozoa. Minyak kelapa juga mengandung sekitar 6-7\% asam kaprat yang juga berfungsi sebagai zat kekebalan tubuh ketika diubah menjadi monokaprin di dalam tubuh manusia atau hewan [7].

Depperin dalam [5] Minyak kelapa sawit merupakan minyak yang mengandung asam palmitat $\left(\mathrm{C}_{16} \mathrm{H}_{32} \mathrm{O}_{2}\right)$ yang cukup tinggi, yaitu sebesar $44,3 \%$. Fungsi dari asam palmitat ini dalam pembuatan sabun adalah untuk kekerasan sabun dan menghasilkan busa yang stabil. Konsumen beranggapan bahwa sabun dengan busa yang melimpah mempunyai kemampuan membersihkan kotoran dengan baik [8]. Minyak zaitun merupakan minyak yang berasal dari perasan buah zaitun, sedangkan minyak zaitun extra virgin adalah hasil olahan pertama, tanpa campuran ekstrak lainnya.

\section{ANOVA}

Analisis of variance atau ANOVA merupakan salah satu teknik analisis multivariate yang berfungsi untuk membedakan rerata lebih dari dua kelompok data dengan cara membandingkan variansinya. Analisis varian banyak dipergunakan pada penelitianpenelitian yang banyak melibatkan pengujian komparatif yaitu menguji variabel terikat dengan cara membandingkannya pada kelompok-kelompok sampel independen yang diamati.

One way anova, yaitu analisis ragam satu arah yang merupakan suatu prosedur untuk menguji rata-rata atau pengaruh perlakuan dari beberapa populasi (lebih dari dua) dari suatu percobaan yang menggunakan satu faktor, dimana satu faktor tersebut memiliki dua atau lebih level. Untuk mengujinya menggunakan tabel anova berikut ini:

Tabel 1. One Way Anova

\begin{tabular}{ccccc}
\hline Source Of Variation & Sum Of Square & Degree Of Freedom & Mean Square & Fo \\
\hline $\begin{array}{c}\text { Between treatment } \\
\text { Error (within treatments) }\end{array}$ & $\mathrm{n} \sum_{i=1}^{a}(\overline{\mathrm{y}} \cdot-\overline{\mathrm{y}} . .)^{2}$ & $\mathrm{a}-1$ & $\mathrm{MS}_{\text {Treatments }}$ & $\frac{\mathrm{MS}_{\text {Treatments }}}{\mathrm{SS}_{\mathrm{T}}-\mathrm{SS}}$ \\
\hline Total & $\sum_{i=1}^{a} \sum_{j=1}^{n}\left(\overline{\mathrm{y}}_{\mathrm{i}} j-\overline{\mathrm{y}} . .\right)^{2}$ & $\mathrm{~N}-1$ & & \\
& & & & \\
\hline
\end{tabular}

Untuk menguji apakah hipotesis dari penelitian akan tolak $\mathrm{H}_{0}$ atau $\mathrm{H}_{1}$ maka digunakan tabel nilai $\mathrm{f}$ dengan cara melihat nilai dari $\mathrm{F}_{20.05}$; a-1; $\mathrm{N}$-a pada tabel $\mathrm{f}$, dengan ketentuan berikut: 
- Jika $\mathrm{F}_{0}>\mathrm{F}_{\text {tabel }}$ maka tolak $\mathrm{H}_{0}$ dan terima $\mathrm{H}_{1}$

- Jika $\mathrm{F}_{0}<\mathrm{F}$ tabel maka tolak $\mathrm{H}_{1}$ dan terima $\mathrm{H}_{0}$

\section{Pengambilan Keputusan Metode Analitycal Hierarchy Process (AHP)}

Salah satu model yang dapat digunakan sebagai proses pengambilan keputusan adalah dengan menggunakan Proses Hierarki Analitik atau yang dikenal dengan istilah Analytical Hierarchy Process (AHP). Proses Hierarki Analitik (AHP) dikembangkan oleh Dr. Thomas L. Dengan menggunakan AHP, suatu persoalan yang akan dipecahkan dalam suatu kerangka berpikir yang terorganisir, sehingga memungkinkan dapat diekspresikan untuk mengambil keputusan yang efektif atas persoalan tersebut. Persoalan yang kompleks dapat disederhanakan dan dipercepat proses pengambilan keputusannya [9].

\section{METODE PENELITIAN}

Dalam Penelitian tim peneliti menggunakan metode penelitian studi kasus dan melakukan percobaan dengan menggunakan 4 perbandingan konsentrasi bahan. Menurut M Nazir [10], metode studi kasus adalah metode penelitian tentang status subyek penelitian yang berkenaan dengan suatu fase spesifik atau khas dari keseluruhan personalitas.

Varibel terikat (dependent variable) pada proses pembuatan sabun pada penelitian ini adalah penggunaan tiga jenis minyak (minyak sawit, minyak kelapa dan minyak zaitun). Minyak yang digunakan minyak dengan kualitas yang baik yang ditandai dengan adanya logo halal pada setiap minyak yang digunakan. Sedangkan variabel bebas (independent varibel) dalam penelitian ini adalah penggunaan $\mathrm{NaOH}$ dengan persentase $\mathrm{NaOH}$ nya $5 \%$, $7,5 \%, 10 \%$ dan $12,5 \%$ dari total bahan yang di gunakan untuk membuat sabun ramah lingkungan.

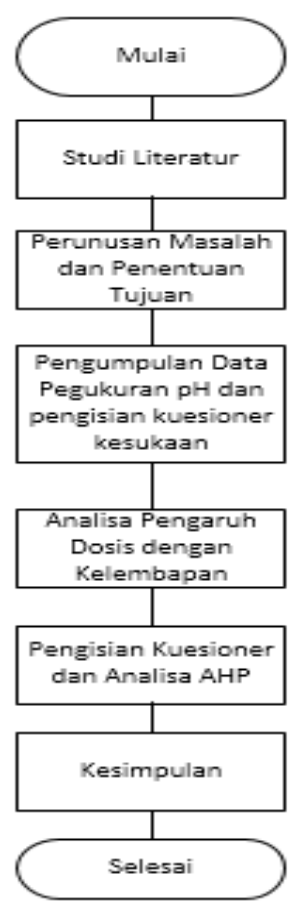

Gambar 1. Flowchart Penelitian

\section{HASIL DAN PEMBAHASAN \\ Pengumpulan Data}

Proses pembuatan sabun memerlukan peralatan yang bersih dan steril, begitu juga dengan tempat pembuatannya. Berikut merupakan alat dan bahan yang diperlukan dalam pembuatan sabun mandi. Alat yang digunakan pada pembuatan sabun mandi padat antara 
lain wadah kaca/panci stainlees steel, hand whisker, spatula karet/plastic, timbangan digital dan cetakan. Adapun bahan yang digunakan minyak kelapa (coconut oil), minyak kelapa sawit (palm oil), minyak zaitun (olive oil), Alkali ( $\mathrm{NaOH}$ ), Air deslilasi (Aquades).

Sedangkan langkah pembuatan sbb: siapkan semua alat dan bahan, tuangkan air ke dalam wadah dan timbang sesuai ukuran, ambil $\mathrm{NaOH}$ di tempat terpisah dan timbang sesuai dengan formula, aduk sampai semua $\mathrm{NaOH}$ larut. Diamkan beberapa saat sampai larutan mencapai suhu dibawah $40^{\circ} \mathrm{C}$, timbang sesuai ukuran dan campur minyak ke dalam wadah yang sudah disediakan, tuagkan minyak pada larutan $\mathrm{NaOH}$ pada suhu sekitar 30$35^{\circ} \mathrm{C}$, aduk secara terus menerus menggunakan hand whisker sampai mencapai trace, siapkan cetakan yang sudah dilapisi plastik atau kertas, tuang ke dalam cetakan, tutup menggunakan kain bekas atau handuk bekas bagian atas cetakandan biarkan selama 1-2 hari, keluarkan sabun dari cetakan. Potong sesuai ukuran yang diinginkan. Simpan di tempat yang kering dengan aliran udara yang baik, biarkan 2-4 minggu, cek pH tiap satu minggu sekali, sabun sudah bisa digunakan jika sudah netral. Siapkan alat dan bahan.

Urutan cara pengukuran $\mathrm{pH}$ pada sabun mandi ramah lingkungan sbb: Standarisasi $\mathrm{pH}$ meter, timbang sabun sebanyak 5 gram, tambahkan aquades sebanyak $45 \mathrm{ml}$ (pengenceran 10\%), celupkan pada $\mathrm{pH}$ meter dan tekan tombol start, tunggu sampai alat menunjukkan angka tetap (setelah bunyi klik), baca hasil pengukuran $\mathrm{pH}$ dan catat, ulangi sebanyak 6 kali replikasi setiap konsentrasi $\mathrm{NaOH}$.

\section{Pengujian Dengan Metode ANOVA (Analysis of Variance)}

Dalam perancangan eksperimen sabun mandi ramah lingkungan ini sabun dilakukan pengujian sebanyak 6 kali. Dengan empat jenis sabun yang beda konsentrasi, warna, aroma, serta bentuk sabun yang dibuat.

\section{Data Hasil Eksperimen}

Data yang diambil dari eksperimen ini adalah data $\mathrm{pH}$ dari sabun mandi ramah lingkungan yang diukur sebanyak 6 kali pada masing-masing dosis $\mathrm{NaOH}$ yang berbeda pada setiap sabun mandi. Sehingga diperoleh data sebagai berikut:

Tabel 2. Data Analisa pH Sabun Mandi Ramah Lingkungan

\begin{tabular}{ccc}
\hline NO & \% NaOH & pH \\
\hline 1 & 5 & 10,38 \\
2 & 5 & 10,34 \\
3 & 5 & 10,19 \\
4 & 5 & 10,22 \\
5 & 5 & 10,17 \\
6 & 5 & 10,18 \\
7 & 7,5 & 10,38 \\
8 & 7,5 & 10,24 \\
9 & 7,5 & 10,38 \\
10 & 7,5 & 10,4 \\
11 & 7,5 & 10,41 \\
12 & 7,5 & 10,33 \\
13 & 10 & 10,23 \\
14 & 10 & 10,22 \\
15 & 10 & 10,29 \\
16 & 10 & 10,37 \\
17 & 10 & 10,51 \\
18 & 10 & 10,44 \\
19 & 12,5 & 12,23 \\
20 & 12,5 & 11,7 \\
21 & 12,5 & 11,6 \\
22 & 12,5 & 12 \\
23 & 12,5 & 11,83 \\
24 & 12,5 & 11,7 \\
\hline
\end{tabular}


Tabel 3. Hasil perhitungan uji normalitas, validitas dan reliabilitas

\begin{tabular}{|c|c|}
\hline Uji & Hasil analisa \\
\hline Normalitas & $\begin{array}{l}\text { Nilai kuantil penguji kolmogorov, alpa }=0,05 \text {, dan } \mathrm{N}=24 \text { adalah } 0,269, \text { pada tabel } \\
\text { kolmogorov smirnov. Nilai } \mathrm{F} \text { hitung maksimal yang diperoleh adalah } 0,237 \text { dan nilai } \mathrm{F} \\
\text { tabel adalah } 0,269 \text {. Maka di peroleh kesimpulan } \mathrm{F} \text { hitung }<\mathrm{F} \text { tabel. Sehingga H0 } \\
\text { diterima dan H1 ditolak. Sehingga dapat disimpulkan bahwa data berdistribusi normal }\end{array}$ \\
\hline Validitas & $\begin{array}{l}\text { Dengan perhitungan uji validitas data keempat konsentrasi sabun mandi ramah } \\
\text { lingkungan, semua data dinyatakan valid karena nilai rhitung }(0,344)>\text { rtabel. }(0,377 \\
\text { untuk konsentrasi } \mathrm{NaOH} 5 \% \text {, } 0,933 \text { untuk konsetrasi } \mathrm{NaOH} 7,5 \%, 0,566 \text { untuk } \\
\text { konsentrasi } \mathrm{NaOH} 10 \% \text { dan } 0,933 \text { untuk konsentrasi } \mathrm{NaOH} 12,5 \%)\end{array}$ \\
\hline Reliabilitas & Interpretasi koefisien reliabilitas untuk uji reliabilitas dikatakan tinggi dengan nilai 0,65 \\
\hline
\end{tabular}

\section{Perhitungan Data dengan metode Anova (Analysis of Variance) Satu Arah}

Tabel 4. Hasil Perhitungan Anova One-Way Software MsExcel

\begin{tabular}{ccccccc}
\hline Source of Variation & $\boldsymbol{S S}$ & $\boldsymbol{d} \boldsymbol{f}$ & $\boldsymbol{M S}$ & $\boldsymbol{F}$ & $\boldsymbol{P}$-value & $\boldsymbol{F}$ crit \\
\hline Between Groups & 10,57388 & 3 & 3,524626 & 177,6152 & $1,4 \mathrm{E}-14$ & 3,098391 \\
Within Groups & 0,396883 & 20 & 0,01984 & & & \\
\hline Total & 10,97076 & 23 & & & & \\
\hline
\end{tabular}

Dengan melakukan perhitungan Anova one way menggunakan perhitungan manual dan Ms Excel dperoleh nilai $f_{\text {hitung }}$ 177,615. Sedangkan untuk nilai $f_{\text {tabel }}$ 3,098.Dengan demikian dapat disimpilkan bahwa $\mathrm{f}_{\text {hitung }}>\mathrm{f}$ tabel, yaitu $177,615<3,098$. Sehingga $\mathrm{H}_{0}$ ditolak dan $\mathrm{H}_{1}$ diterima. Artinya konsentrasi $\mathrm{NaOH} 5 \%$.

\section{Uji Tukey}

Setelah melakukan uji anova satu arah dengan empat konsentrasi dan didapatkan kesimpulan bahwa ada pengaruh dari perbedaan konsentrasi $\mathrm{NaOH}$ yang digunakan. Maka dilakukan uji lanjutan menggunakan metode uji tukey dengan empat konsentrasi tersebut, untuk lebih memastikan konsentrasi $\mathrm{NaOH}$ yang paling tepat digunakan untuk sabun mandi ramah lingkungan. Dimana A : Warna, B : Bentuk, C : Kelembapan, D : Aroma Saat Digunakan dan E: Aroma Setelah Digunakan.

Tabel 5. Data rata-rata $\mathrm{pH}$ Sabun

\begin{tabular}{ccccc}
\hline No & \multicolumn{4}{c}{ Konsentasi NaOH } \\
\hline & $5 \%$ & $7,50 \%$ & $10 \%$ & $12,50 \%$ \\
1 & 10,350 & 10,380 & 10,230 & 12,230 \\
2 & 10,340 & 10,240 & 10,220 & 11,700 \\
3 & 10,190 & 10,380 & 10,290 & 11,600 \\
4 & 10,220 & 10,400 & 10,370 & 12,000 \\
5 & 10,170 & 10,410 & 10,510 & 11,830 \\
6 & 10,180 & 10,330 & 10,440 & 11,700 \\
\hline rata-rata & 10,242 & 10,357 & 10,343 & 11,843 \\
\hline
\end{tabular}

Mse: kuadrat tengah error $=0,020$

dfe : derajat bebas error $=20$

$\mathrm{r} \quad$ : banyak data menghasilkan rata-rata $=6$

$\mathrm{p} \quad$ : jumlah rata-rata yang dibandingkan $=3$

Se : standar error $=0,690$

qa : nilai wilayah studentized range untuk tukey $\operatorname{HSD}$ pada $\alpha, \mathrm{p}$, dan dfe $=5,530$

$\mathrm{W}$ : nilai kritis $=3,530 \times 0,690=2,4357=2 ., 436$ 


\begin{tabular}{ccccc}
\multicolumn{5}{c}{ Tabel 6. Rata-Rata Uji Tukey } \\
\hline \% NaOH & $\mathbf{5}$ & $\mathbf{7 , 5}$ & $\mathbf{1 0}$ & $\mathbf{1 2 , 5}$ \\
\hline 5 & 0 & 0,115 & 0,102 & 1,602 \\
7,5 & & 0 & 0,013 & 1,487 \\
10 & & & 0 & 1,500 \\
12,5 & & & & 0 \\
\hline
\end{tabular}

Perhitungan:

$|\mathrm{A}-\mathrm{B}|=|10,242-10,357|=0,115$

$|A-C|=|10,242-10,343|=0,102$

$|\mathrm{A}-\mathrm{D}|=|10,242-10,843|=1,602$

$|\mathrm{B}-\mathrm{C}|=|10,357-10,343|=0,013$

$|\mathrm{B}-\mathrm{D}|=|10,357-10,843|=1,487$

$|\mathrm{C}-\mathrm{D}|=|10,343-10,843|=1,500$

Dari perhitungan lanjutan menggunakan metode uji tukey, diperoleh data bahwa semua nilai perhitungan < $\mathrm{w}$ (nilai kritis). Jadi kesimpulannya seluruh data memenuhi untuk digunakan. Dengan mempertimbangkan beberapa faktor, terutama faktor produksi maka ditetapkan pemilihan konsentrasi $\mathrm{NaOH}$ yang digunakan adalah 5\%. Dengan melihat biaya produksi, maka $\mathrm{NaOH}$ dengan konsentrasi $5 \%$ adalah paling ekonomis.

\section{Pengumpulan dan Sumber Data \\ Sumber Data}

Pengumpulan data diperoleh dari penyebaran kuesioner dan sampel sabun mandi ramah lingkungan diuji coba kepada 6 orang yang sering berganti-ganti sabun karena merasa sensitif dan tidak puas dengan sabun yang digunakan dan orang yang sudah mengetahui karakteristik sabun mandi yang baik serta yang dibutuhkan oleh sebagian masyarakat. Baik dalam segi aroma, warna, maupun bentuk dari sabun tersebut sehingga memilah-milah sabun yang tepat untuk digunakan.

\section{Menentukan Kriteria}

Hasil diskusi dengan beberapa orang sebagai pengambil keputusan mengenai kriteria sabun mandi yang dibutuhkan untuk orang yang mempunyai keluhan kulit kering dan sensitif terhadap beberapa kandungan dalam sabun mandi komersil yang digunakan untuk membuat sabun mandi, juga orang-orang yang sering mengganti sabun mandi karena alasan tertentu, serta orang yang sudah mengetahui karakteristik sabun yang baik untuk digunakan. Sehingga membutuhkan sabun alami tanpa bahan kimia yang berlebihan dan sesuai dengan kesukaan serta kebutuhan baik aroma maupun bentuk.

Tabel 7. Kriteria Penentuan

\begin{tabular}{ll}
\hline Kriteria & \multicolumn{1}{c}{ Detail } \\
\hline Warna & Ada empat warna sabun yang berbeda yang digunakan, namun tetap \\
& menggunakan pewarna alami. Warna mana yang paling menarik untuk \\
dijadikan sabun dengan pewangi masing - masing. & \\
Bda empat bentuk dalam pembuatan sabun ini, yaitu bentuk kotak, oval, & piramid dan kaki kucing. Bentuk mana yang paling disukai wanita. \\
Kelembapan & Ada empat kadar NaOH yang berbeda, yaitu 5\%, 7,5\%, 10\%, dan 12,5\%. \\
& Apakah kelembapan terasa berbeda setelah menggunakan sabun dengan \\
& konsentrasi NaOH yang berbeda. \\
Aroma saat digunakan & Sabun yang dibuat menggunakan empat pewangi yang berbeda, yaitu jasmine, \\
& rose, fragrance, dan lavender. Bagaimana aroma yang keluar dari sabun mandi \\
& ketika digunakan. \\
Aroma setelah digunakan & Ini sama dengan sebelumya, hanya perbedaan penilaian pada aroma sabun \\
& setelah digunakan masih sama atau tidak.
\end{tabular}


Selamet Riadi, Dede Rukmayadi, Iwan Roswandi, Roy Wangitan

Dari kriteria tersebut selanjutnya dibuat Hierarki untuk keputusan apakah ada perbedaan yang signifikan terhadap sabun mandi dengan perbedaan konsentrasi $\mathrm{NaOH}$.

\section{Penyusunan Hirarki}

Dalam pemilihan konsentrasi $\mathrm{NaOH}$ dengan 4 konsentrasi yaitu 5\%, 7,5\%, $10 \%$ dan 12,5\% maka dilakukan perhitungan dengan 3 konsentrasi karena konsentrasi 12,5\% melebihi standar sabun mandi yang ditetapkan. Dan karena $\mathrm{pH}$ sabun pada konsentrasi 5\%, $7,5 \%$, dan $10 \%$ berpengaruh, maka hirarki yang disusun berdasarkan warna, bentuk, kelembapan, aroma saat digunakan, dan aroma setelah digunakan.

\section{Struktur Hirarki Masalah}

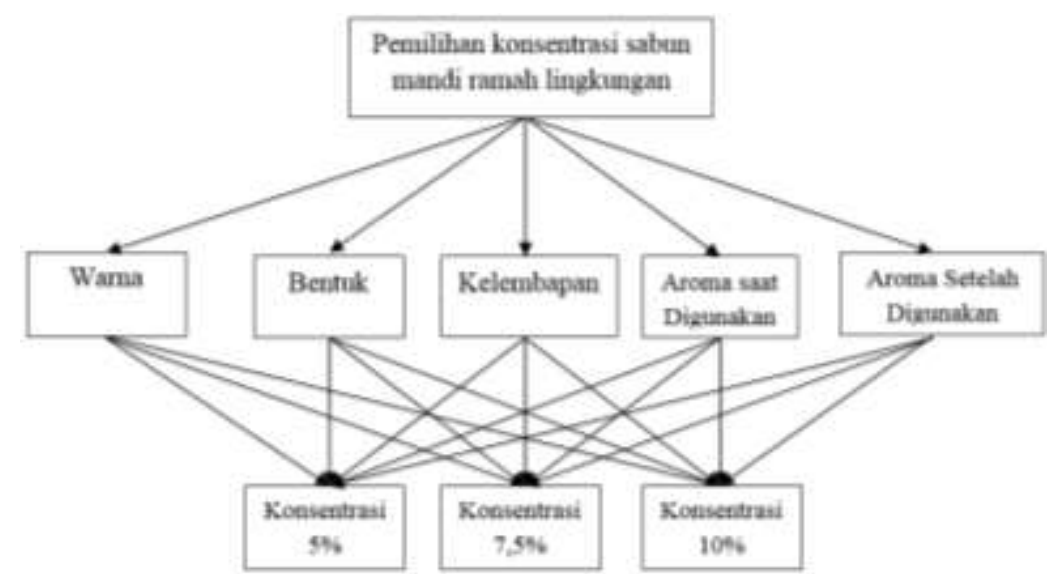

Gambar 2. Struktur Hierarki Masalah

\section{Pengolahan Data}

Dari hasil penilaian 6 responden, maka didapat hasil matriks perbandingan berpasangan dalam pemilihan kriteria sabun mandi dengan menggunakan metode geometric mean

Tabel 8. Matriks Perbandingan Data Perbandingan Kriteria Pakar 1 dan 2

\begin{tabular}{ccccccccccc}
\hline \multirow{2}{*}{ Kriteria } & \multicolumn{4}{c}{ Pakar 1 } & \multicolumn{1}{c}{ Pakar 2 } \\
\cline { 2 - 11 } & $\mathbf{A}$ & $\mathbf{B}$ & $\mathbf{C}$ & $\mathbf{D}$ & $\mathbf{E}$ & $\mathbf{A}$ & $\mathbf{B}$ & $\mathbf{C}$ & $\mathbf{D}$ & $\mathbf{E}$ \\
\hline A & 1,00 & 1,00 & 9,00 & 4,00 & 5,00 & 1,00 & 3,00 & 4,00 & 6,00 & 8,00 \\
B & 1,00 & 1,00 & 9,00 & 2,00 & 3,00 & 0,33 & 1,00 & 4,00 & 4,00 & 6,00 \\
C & 0,11 & 0,11 & 1,00 & 0,11 & 0,11 & 0,25 & 0,25 & 1,00 & 5,00 & 4,00 \\
D & 0,25 & 0,50 & 9,00 & 1,00 & 3,00 & 0,17 & 0,25 & 0,20 & 1,00 & 2,00 \\
E & 0,20 & 0,33 & 9,00 & 0,33 & 1,00 & 0,13 & 0,17 & 0,25 & 0,50 & 1,00 \\
\hline Total & 2,561 & 2,944 & 37,000 & 7,444 & 12,111 & 1,88 & 4,67 & 9,45 & 16,50 & 21,00 \\
\hline \multicolumn{1}{c}{} & CR & & & 0,0907 & \multicolumn{3}{c}{ CR } & & 0,0858 \\
\hline
\end{tabular}

Tabel 9. Matriks Perbandingan Data Perbandingan Kriteria Pakar 3 dan 4

\begin{tabular}{ccccccccccc}
\hline \multirow{2}{*}{ Kriteria } & \multicolumn{4}{c}{ Pakar 3 } & \multicolumn{1}{c}{ Pakar 4 } \\
\cline { 2 - 11 } & $\mathbf{A}$ & $\mathbf{B}$ & $\mathbf{C}$ & $\mathbf{D}$ & $\mathbf{E}$ & $\mathbf{A}$ & $\mathbf{B}$ & $\mathbf{C}$ & $\mathbf{D}$ & $\mathbf{E}$ \\
\hline $\mathrm{A}$ & 1,00 & 2,00 & 7,00 & 5,00 & 6,00 & 1,00 & 3,00 & 5,00 & 9,00 & 5,00 \\
$\mathrm{~B}$ & 0,50 & 1,00 & 7,00 & 4,00 & 2,00 & 0,33 & 1,00 & 3,00 & 3,00 & 6,00 \\
$\mathrm{C}$ & 0,14 & 0,14 & 1,00 & 3,00 & 1,00 & 0,20 & 0,33 & 1,00 & 5,00 & 3,00 \\
$\mathrm{D}$ & 0,20 & 0,25 & 0,33 & 1,00 & 0,25 & 0,11 & 0,33 & 0,20 & 1,00 & 0,25 \\
E & 0,17 & 0,50 & 1,00 & 4,00 & 1,00 & 0,20 & 0,17 & 0,33 & 4,00 & 0,50 \\
\hline Total & 2,010 & 3,893 & 16,333 & 17,000 & 10,250 & 1,844 & 4,833 & 9,533 & 22,000 & 14,750 \\
\hline \multicolumn{1}{l}{} & & CR & & & 0,0986 & \multicolumn{3}{c}{ CR } & & 0,0969 \\
\hline
\end{tabular}


Tabel 10. Matriks Perbandingan Data Perbandingan Kriteria Pakar 5 dan 6

\begin{tabular}{|c|c|c|c|c|c|c|c|c|c|c|}
\hline \multirow{2}{*}{ Kriteria } & \multicolumn{4}{|c|}{ Pakar 5} & & \multicolumn{5}{|c|}{ Pakar 6} \\
\hline & $\mathbf{A}$ & B & $\mathrm{C}$ & D & $\mathbf{E}$ & $\mathbf{A}$ & B & C & D & $\mathbf{E}$ \\
\hline $\mathrm{A}$ & 1,00 & 2,00 & 4,00 & 5,00 & 2,00 & 1,00 & 1,00 & 2,00 & 8,00 & 5,00 \\
\hline B & 0,50 & 1,00 & 8,00 & 8,00 & 3,00 & 1,00 & 1,00 & 6,00 & 5,00 & 9,00 \\
\hline $\mathrm{C}$ & 0,25 & 0,13 & 1,00 & 4,00 & 0,33 & 0,50 & 0,17 & 1,00 & 2,00 & 1,00 \\
\hline $\mathrm{D}$ & 0,20 & 0,13 & 0,25 & 1,00 & 0,17 & 0,13 & 0,20 & 0,50 & 1,00 & 3,00 \\
\hline $\mathrm{E}$ & 0,50 & 0,33 & 3,00 & 6,00 & 1,00 & 0,20 & 0,11 & 1,00 & 0,33 & 1,00 \\
\hline Total & 2,450 & 3,583 & 16,250 & 24,000 & 6,500 & 2,825 & 2,478 & 10,500 & 16,333 & 19,000 \\
\hline
\end{tabular}

Tabel 11. Rata Rata geometrik konsentrasi $\mathrm{NaOH}$

\begin{tabular}{llllll}
\hline Kriteria & A & B & C & D & E \\
\hline A & 1,0000 & 1,8171 & 4,6478 & 5,9235 & 4,7848 \\
B & 0,5503 & 1,0000 & 5,7539 & 3,9572 & 4,2426 \\
C & 0,2152 & 0,1738 & 1,0000 & 2,0137 & 0,8736 \\
D & 0,1688 & 0,2527 & 0,4966 & 1,0000 & 0,7565 \\
E & 0,2090 & 0,2357 & 1,1447 & 1,3218 & 0,8909 \\
\hline Total & 2,1433 & 3,4793 & 13,0430 & 14,2162 & 11,5485 \\
\hline
\end{tabular}

\section{Bobot Proiritas Perbandingan Kriteria Dalam Pemilihan Konsentrasi NaOH}

Dari hasil perhitungan perbandingan berpasangan antar variabel dalam pemilihan konsentrasi $\mathrm{NaOH}$ diperoleh bobot prioritas. Nilai bobot prioritas dihasilkan dari rata-rata bobot relatif untuk setiap baris.

Tabel 12. Prioritas Kepentingan (Bobot) Kriteria Dalam Pemilihan Konsentrasi $\mathrm{NaOH}$

\begin{tabular}{lllllll}
\hline Kriteria & A & B & C & D & E & Bobot Prioritas \\
\hline A & 0,4666 & 0,5223 & 0,3563 & 0,4167 & 0,4143 & 0,4352 \\
B & 0,2568 & 0,2874 & 0,4411 & 0,2784 & 0,3674 & 0,3262 \\
C & 0,1004 & 0,0500 & 0,0767 & 0,1416 & 0,0756 & 0,0889 \\
D & 0,0788 & 0,0726 & 0,0381 & 0,0703 & 0,0655 & 0,0651 \\
E & 0,0975 & 0,0677 & 0,0878 & 0,0930 & 0,0771 & 0,0846 \\
\hline Total & & & & & & 1,0000 \\
\hline
\end{tabular}

\section{Pengujian Konsistensi Terhadap Kriteria Konsentrasi NaOH}

Nilai Eigen Vector dan Eigen Value kriteria

$$
0,4352\left(\begin{array}{l}
1,0000 \\
0,5503 \\
0,2152 \\
0,1688 \\
0,2090
\end{array}\right)+0,3262\left(\begin{array}{l}
1,8171 \\
1,0000 \\
0,1738 \\
0,2527 \\
0,2357
\end{array}\right)+0,0889\left(\begin{array}{l}
4,6478 \\
5,7539 \\
1,0000 \\
0,4966 \\
1,1447
\end{array}\right)+0,0651\left(\begin{array}{l}
5,9235 \\
3,9572 \\
2,0137 \\
1,0000 \\
1,3218
\end{array}\right)+0,0846\left(\begin{array}{l}
4,7848 \\
4,2426 \\
0,8736 \\
0,7565 \\
0,8909
\end{array}\right)=\left(\begin{array}{l}
2,2313 \\
1,6935 \\
0,4442 \\
0,3291 \\
0,4309
\end{array}\right)
$$

Nilai eigen value didapat dengan membagi nilai hasil eigen vector dengan bobot prioritas, sebagai berikut ini:

$$
\frac{2,2313}{0,4352}=5,1268, \frac{1,6935}{0,3262}=5,1915, \frac{0,4442}{0,0889}=4,9983, \frac{0,3291}{0,0651}=5,0585, \frac{0,4309}{0,0846}=5,0925
$$

Nilai $\lambda$ maksimum

Nilai $\lambda$ didapat dengan menjumlahkan nilai eigen value dibagi dengan jumlah kriteria, perhitungannya sebagai berikut:

\section{Nilai Konsistensi Index (CI)}

$$
\lambda_{\text {maksimum }}=\frac{5,1268+5,1915+4,9985+5,0585+5,0925}{5}=5,0935
$$

Menghitung nilai konsistensi index yang terdiri dari 5 (lima) kriteria, nilai konsistensi index yang diperoleh:

$$
C I=\frac{5,0935-5}{5-1}=0,0234
$$


Nilai Konsistensi Ratio (CR)

Nilai indeks random konsistensi (RI) dengan jumlah ordo matriks 5 (lima), $\mathrm{n}=5$, RI $=1,12$ (didapat dari tabel nilai random indeks), maka nilai konsistensi ratio:

$$
C R=\frac{0,0234}{1.12}=0,009<0,1
$$

Karena CR $<0,1$ berarti preferensi pakar adalah konsisten.

\section{Data Hasil Perbandingan Konsentrasi NaOH Berdasarkan Kriteria Warna}

Dari hasil penilaian 6 pakar, maka didapat matriks hasil perbandingan konsentrasi $\mathrm{NaOH}$ berdasarkan kriteria warna dengan menggunakan metode geometric mean.

Tabel 13. Matriks Perbandingan Konsentrasi NaOH Berdasarkan Kriteria Warna

Pakar 1, 2 dan 3

\begin{tabular}{cccccccccc}
\hline \multirow{2}{*}{ \% NaOH } & \multicolumn{3}{c}{ Pakar 1 } & \multicolumn{3}{c}{ Pakar 2 } & \multicolumn{3}{c}{ Pakar 3 } \\
\cline { 2 - 11 } & $\mathbf{5}$ & $\mathbf{7 , 5}$ & $\mathbf{1 0}$ & $\mathbf{5}$ & $\mathbf{7 , 5}$ & $\mathbf{1 0}$ & $\mathbf{5}$ & $\mathbf{7 , 5}$ & $\mathbf{1 0}$ \\
\hline 5 & 1,00 & 3,00 & 9,00 & 1,00 & 4,00 & 5,00 & 1,00 & 5,00 & 6,00 \\
7,5 & 0,33 & 1,00 & 4,00 & 0,25 & 1,00 & 3,00 & 0,20 & 1,00 & 3,00 \\
10 & 0,11 & 0,25 & 1,00 & 0,20 & 0,33 & 1,00 & 0,17 & 0,33 & 1,00 \\
\hline total & 1,44 & 4,25 & 14,00 & 1,45 & 5,33 & 9,00 & 1,37 & 6,33 & 10,00 \\
\hline
\end{tabular}

Tabel 14. Matriks Perbandingan Konsentrasi NaOH Berdasarkan Kriteria Warna Pakar 4, 5 dan 6

\begin{tabular}{cccccccccc}
\hline \multirow{2}{*}{$\%$ NaOH } & \multicolumn{3}{c}{ Pakar 4 } & \multicolumn{3}{c}{ Pakar 5 } & \multicolumn{3}{c}{ Pakar 6 } \\
\cline { 2 - 10 } & $\mathbf{5}$ & $\mathbf{7 , 5}$ & $\mathbf{1 0}$ & $\mathbf{5}$ & $\mathbf{7 , 5}$ & $\mathbf{1 0}$ & $\mathbf{5}$ & $\mathbf{7 , 5}$ & $\mathbf{1 0}$ \\
\hline 5 & 1,00 & 0,25 & 2,00 & 1,00 & 4,00 & 8,00 & 1,00 & 8,00 & 3,00 \\
7,5 & 4,00 & 1,00 & 3,00 & 0,25 & 1,00 & 5,00 & 0,13 & 1,00 & 0,50 \\
10 & 0,50 & 0,33 & 1,00 & 0,13 & 0,20 & 1,00 & 0,33 & 2,00 & 1,00 \\
\hline total & 5,50 & 1,58 & 6,00 & 1,38 & 5,20 & 14,00 & 1,46 & 11,00 & 4,50 \\
\hline
\end{tabular}

Tabel 15. Matriks Perbandingan konsentrasi NaOH Berdasarkan Kriteria Warna

\begin{tabular}{cccc}
\hline \% NaOH & $\mathbf{5}$ & $\mathbf{7 , 5}$ & $\mathbf{1 0}$ \\
\hline 5 & 1,00 & 2,80 & 4,85 \\
7,5 & 0,36 & 1,00 & 2,54 \\
10 & 0,21 & 0,39 & 1,00 \\
\hline total & 1,56 & 4,19 & 8,39 \\
\hline
\end{tabular}

\section{Menghitung Bobot Proiritas Perbandingan Berpasangan Kriteria Warna}

Dari hasil perhitungan perbandingan berpasangan antar variabel dalam pemilihan konsentrasi $\mathrm{NaOH}$ kriteria warna diperoleh bobot prioritas. Nilai bobot prioritas dihasilkan dari rata-rata bobot relatif untuk setiap baris.

Tabel 16. Prioritas Kepentingan (Bobot) Konsentrasi NaOH Berdasarkan Kriteria Warna

\begin{tabular}{ccccc}
\hline $\mathbf{\%} \mathbf{~ N a O H}$ & $\mathbf{5}$ & $\mathbf{7 , 5}$ & $\mathbf{1 0}$ & $\mathbf{V P}$ \\
\hline 5 & 0,640 & 0,668 & 0,578 & 0,628 \\
7,5 & 0,229 & 0,239 & 0,303 & 0,257 \\
10 & 0,132 & 0,094 & 0,119 & 0,115 \\
total & & & & 1,000 \\
\hline
\end{tabular}

\section{Pengujian Konsistensi Terhadap Kriteria Warna}

Menghitung Eigen Vector dan Eigen Value kriteria

$$
0,628\left(\begin{array}{l}
1,00 \\
0,36 \\
0,21
\end{array}\right)+0,257\left(\begin{array}{l}
2,80 \\
1,00 \\
0,39
\end{array}\right)+0,115\left(\begin{array}{l}
4,85 \\
2,54 \\
1,00
\end{array}\right)=\left(\begin{array}{l}
1,904 \\
0,774 \\
0,346
\end{array}\right)
$$


Kemudian menghitung eigen value didapat dengan membagi nilai hasil eigen vector dengan bobot prioritas, sebagai berikut ini:

$$
\frac{1,904}{0,628}=3,031, \frac{0,774}{0,257}=3,013, \frac{0,346}{0,115}=3,005
$$

\section{Menghitung $\lambda$ maksimum}

Nilai $\lambda$ didapat dengan menjumlahkan nilai eigen value dibagi dengan jumlah kriteria, perhitungannya sebagai berikut:

$$
\lambda_{\text {maksimum }}=\frac{3,031+3,013+3,005}{3}=3,016
$$

\section{Menghitung Konsistensi Index (CI)}

Menghitung nilai konsistensi index yang terdiri dari 3 (tiga) kriteria, nilai konsistensi index yang diperoleh:

$$
C I=\frac{3,016-3}{3-1}=0,005
$$

\section{Menghitung Indeks Random Konsistensi (RI)}

Menghitung indeks random konsistensi (RI) dengan jumlah ordo matriks 3 (tiga), $\mathrm{n}=$ $3, \mathrm{RI}=0,58$ (didapat dari tabel nilai random indeks), maka:

$$
C R=\frac{0,005}{0,58}=0,009<0,1
$$

Karena CR $<0,1$ berarti preferensi pakar adalah konsisten.

Perhitungan serupa juga dilakukan pada kriteria lainnya yaitu bentuk, kelembapan, aroma saat digunakan dan aroma setelah digunakan. Setelah dilakukan perhitungan maka didapatkan nilai CR (consistensi ratio) sebagai berikut:

\begin{tabular}{cc}
\multicolumn{2}{c}{ Tabel 17. Nilai CR (consistensi ratio) } \\
\hline Kriteria & nilai CR (consistensi ratio) \\
\hline Warna & 0,009 \\
Bentuk & 0,005 \\
Kelembapan & 0,000 \\
Aroma saat digunakan & 0,005 \\
Aroma setelah digunakan & 0,022 \\
\hline
\end{tabular}

Dari data tersebut, didapatkan nilai CR (consistensi ratio) $<0,01$, yang berarti bahwa seluruh data dara preferensi pakar sabun mandi adalah konsisten.

\section{Prioritas Global}

Dari hasil penilaian 6 pakar, bobot prioritas total didapat dari hasil evaluasi yang dilakukan terhadap 5 (lima) kriteria yakni yang dikalikan dengan vektor prioritas, maka diperoleh tabel hubungan antara kriteria dan alternatif.

Tabel 18. Matriks Perbandingan Bobot Prioritas Kriteria Dengan Bobot Prioritas Alternatif

\begin{tabular}{ccccccc}
\hline & $\mathbf{A}$ & $\mathbf{B}$ & $\mathbf{C}$ & $\mathbf{D}$ & $\mathbf{E}$ & \\
& $(\mathbf{0 , 4 3 5})$ & $(\mathbf{0 , 3 2 6})$ & $(\mathbf{0 , 0 8 9 )}$ & $(\mathbf{0 , 0 6 5 )}$ & $(\mathbf{0 , 0 8 5})$ & VP total \\
\hline $5 \%$ & 0,628 & 0,535 & 0,601 & 0,626 & 0,504 & 0,585 \\
$7,50 \%$ & 0,257 & 0,251 & 0,242 & 0,173 & 0,362 & 0,257 \\
$10 \%$ & 0,115 & 0,214 & 0,157 & 0,202 & 0,134 & 0,158 \\
\hline
\end{tabular}

Jadi, dengan data tersebut diperoleh kesimpulan bahwa sabun yang paling disukai dan dibutuhkan oleh masyarakat adalah dengan menggunakan $\mathrm{NaOH}$ sebanyak 5\% dengan nilai vektor prioritas tertinggi. 


\section{KESIMPULAN}

Dengan melakukan perhitungan data $\mathrm{pH}$ sabun mandi ramah lingkungan dengan menggunakan metode Anova satu arah, didapatkan hasil bahwa konsentrasi $\mathrm{NaOH}$ $5 \%, 7,5 \%, 10 \%$, dan $12,5 \%$ mempengaruhi hasih $\mathrm{pH}$ dari sabun mandi. Artinya terjadi perbedaan pada $\mathrm{pH}$ sabun mandi tersebut dengan perbedaan konsentrasi $\mathrm{NaOH}$. Dengan perhitungan validitas reliabilitas dan uji tukey, konsentrasi $\mathrm{NaOH}$ yang paling tepat digunakan untuk sabun mandi adalah 5\%.Untuk pengambilan keputusan dengan metode perhitungan AHP maka diperoleh hasil sabun mandi yang paling disukai oleh masyarakat adalah sabun mandi dengan konsentrasi 5\%. Dengan nilai bobot akhir yang paling tinggi yaitu 0,585.Perhitungan tersebut selaras dengan perhitungan anova, validitas, reliabilitas dan uji tukey, bahwa $\mathrm{NaOH}$ yang paling tepat digunakan untuk sabun mandi adalah $\mathrm{NaOH}$ dengan konsentrasi $5 \%$.

\section{DAFTAR PUSTAKA}

[1] F. Nursyahidah, "Penelitian Eksperimen," 2012. [Online]. Available: https:// faridanursyahidah.files.wordpress.com/2012/05/penelitian-eksperimen_farid\%0Aa. pdf.

[2] A. Jaedun, "Metodologi Penelitian Ksperimen," Metodol. Penelit. Eksperimen, pp. 012, 2011.

[3] R. Ary, Donald, Jacobs, L., C., Introduction To Research in Education. New York: Holt, Rinehart., 2009.

[4] R. P. Usmania, I.D.A., \& Widya, "Pembuatan Sabun Transparan Dari Minyak Kelapa Murni (Virgin Coconut Oil)," Universitas Sebelas Maret., 2012.

[5] A. Widyasanti, C. L. Farddani, and D. Rohdiana, "Pembuatan Sabun Padat Transparan Menggunakan Minyak Kelapa Sawit ( Palm Oil ) Dengan Penambahan Bahan Aktif Ekstrak Teh Putih ( Camellia Sinensis ) Making Of Transparent Solid Soap Using Palm Oil Based With Addition White Tea Extracts ( Camellia sinensis," J. Tek. Pertan. Lampung, vol. 5, no. 3, pp. 125-136, 2016.

[6] R. N. Febriyenti, Lisa Indah Sari, "Formulasi Sabun Transparan Mintak Ylang-Ylang dan Uji Efektivitasterhadap Bakteri Penyebab Jerawat," J. Sains Farm. Klin., vol. 1, no. $1,2014$.

[7] W. Darmoyuwono, Gaya Hidup Sehat Dengan Virgin Coconut Oil. Jakarta: PT. Indeks Kelompok Gramedia, 2006.

[8] M. Izhar, Sumiati, "Analisis Sikap Konsumen terhadap Atribut Sabun Mandi," Univ. Brawijaya. Malang, 2009.

[9] M. N. Maghfiroh, Aplikasi Teknik Pengambilan Keputusan dalam Manajemen Rantai pasok. Bogor: PT. Penerbit IPB Press, 2010.

[10]M. Nazir, Metode Penelitian. Jakarta: Ghalia Indonesia., 2011. 